\title{
せん断モデルを用いた離散剛要素法の材料定数の検討

\author{
STUDY ON MATERIAL CONSTANTS OF DISTINCT ELEMENT METHOD \\ USING SHEAR MODELS
}

\author{
木山英 郎*・藤村尚**・西村強*** \\ By Hideo KIYAMA, Hisashi FUJIMURA and Tsuyoshi NISHIMURA
}

\begin{abstract}
The distinct element method (DEM) have the potential applicability for analysis of fissured rock structures and granular materials. Before its practical application, a suitable procedure for determining material constants of elements should be developed. In the case of rock structures, the size of element is large enough to be made a specimen, and two procedures of determination of material constants $K, \eta$ have been proposed by the authors. In the case of granular materials, however, the size of elements is too small to be tested individually. Mechanical properties of soil are used to be described in terms of the shear strength constants $c, \phi$. It will be expected useful that the $K, \eta$ can be determined with respect to the $c, \phi$. In this paper, models of simple and direct shear test are analyzed by DEM, and the relationships among the $K, \eta$, the particle arrangement and the $c, \phi$ are discussed.

Keywords: DEM, granular material, material constants, shear model
\end{abstract}

\section{1. 緒言}

離散剛要素法（以下, DEM と略記する）は亀裂性岩 盤の解析法として Cundall $(1971)^{11}$ によって提案された. DEM は, 不連続な要素の集合体に対し，個々の要素が 運動方程式を満足し, 要素間の力の伝達が作用・反作用 の法則に従うことを条件として，集合体の動力学的挙動 を数値解析するものである. DEM が亀裂性岩盤のみな らず土構造物や一般粒状体の実用的な数值解析法として 認められるためには解析に必要な材料定数をいかに合理 的に決定するかを明らかにされなければならない．

DEM 解析における材料定数としては要素と要素の法 線方向の接触力〜変位関係を表わすフォークトモデルの ばね定数 $K_{n}$ 之粘性定数 $\eta_{n}$, 同様に接線方向の定数 $K_{s}$ と $\eta_{s}$, および粒子間 (要素間) 摩擦角 $\phi_{\mu}$ が重要である (詳細は参考文献 2 を参照されたい).

これら材料定数 $K, \eta$ の決定法として弾性接触理論に 基づく方法 ${ }^{21}$ および落下反発試験による方法 ${ }^{3)}$ を提案し ている．粒子径が十分大きく，個々の粒子を供試体とし

\footnotetext{
* 正会員 工博 鳥取大学教授 工学部海洋土木工学科 ( ( 680 鳥取市湖山町南 4-101)

** 正会員 工博 鳥取大学助教授 工学部海洋土木工学科 (同上)

*** 正会員 工修 鳥取大学助手 工学部土木工学科 (同上)
}

て実験できる場合には，この方法により，合理的に材料 定数 $K, \eta$ が求められる. しかしながら, 土や粉体のよ うに小さな粒子の集合体の場合には，個々の粒子につい て材料定数 $K, \eta$ を決定することは困難であり，むしろ 単純な集合体特性から要素特性としての材料定数 $K, \eta$ を決定できれば実用的と思われる. 土や粒状体の力学特 性が, 通常, 世九断強度定数 $c, \phi$ で表現されることか ら, 材料定数 $K, \eta$ の決定法の検討あるいは解析結果之 実挙動の対応性の検討(4) 行うとき，まず，第一に集合 体特性としての $c, \phi$ と $K, \eta$ の関係を明らかにしてお くことが有用である. とはいえ, 土の変形・強度特性が 間隙比で代表される骨格構造に強く依存する性質を考え るとき, DEM においても $c, \phi$ は単に材料定数 $K, \eta$ にのみ依存するものでなく, 粒子配列等に関連した定数 とならざるを得ないものと思われる.

以上の観点から，本報においては砂のような粒状体を 対象に, 単純せん断試験と一面せん断試験をモデル化し, DEM 解析によって得られた $c, \phi$ と材料定数および粒 子配列とのかかわり合いについて考察する.

\section{2. せん断モデルの概要}

せん断試験法として，単純せん断試験と一面せん断試 験を考え，ひずみ速度一定の条件で以下のような DEM 
モデルを設定した。

せん断容器として，Fig. 1 にみられるように底辺 40 $\mathrm{cm}$ ，高さ $20 \mathrm{~cm}$ を有する単位厚さの二次元モデルを考 える．単純せん断の場合，壁 $\mathrm{AD}, \mathrm{BC}$ が平行を保ちつ つ，それぞれ点 $\mathrm{A}, \mathrm{B}$ を中心として $0.05(\mathrm{rad} / \mathrm{s})$ なる 速度で回転して変形を与える。また，一面せん断試験の 場合，辺 $\mathrm{EF}$ をせん断面として上部が右方へ $1.0(\mathrm{~cm} / \mathrm{s})$ なる速度で移動して変形を与える。これらの速度は, 砂 質試料に対する通常の急速せん断速度よりかなり速い

(約 10 倍) が，それによる解の安定性は時間増分 $\Delta t$ に依存する．本例で用いた供試体の寸法は標準寸法の約 10 倍と大きく，時間増分 $\Delta t=10^{-4} \mathrm{~s}$ 以下で解析結果に ほとんど差のないことから，上述のようなせん断速度を 採用した。

圧密，せん断を通じて載荷板 $C D$ は圧縮荷重に相当 する自重をもった剛板要素として導入し，上下方向にの み自由に運動でき，水平方向は上記のせん断速度に強制 され，回転は 0 に拘束した。

この容器に, 半径 $1 \mathrm{~cm}$ の円形要素を左右対称に配置 し，最下段に $n$ 個，その上に $(n-1)$ 個の順に規則正 しく配列（以下， $(n-1) / n$ 配列とよぶ）する。こうし てできる一要素 4 接点の規則配列のうち, 代表として, $17 / 18 ， 15 / 16 ， 13 / 14 ， 11 / 12$ 配列の 4 配列を中心に解 析した。

要素の諸元と, これより, 求められる材料定数 $K, \eta^{2), 3)}$ を Table 1 にまとめて示している. せん断箱の底壁と載 荷板ならびに側壁と要素との接触に関する定数のうち, 壁面摩擦角 $\phi_{w}$ 值は底壁と載荷板ではせん断荷重の伝達 を考えて十分に大きくとり，側壁部では供試体の体積 変化を妨げないようできるだけ小さくとり，それぞれ $\tan \phi_{w}=1.0$ と 0.087 とした。

せん断過程における鉛直応力 $\sigma_{x}$ とせん断応力 $\tau_{x y}$ は, 供試体内の水平せん断面上の平均的な値として次のよう に定めた。全要素間の接触力ベクトルの中, 上方から下 方へ,あるいは下方から上方へのいずれか片方について， 鉛直成分の総和および水平成分の総和を求め, それぞれ を（層数ー1)×40 $(\mathrm{cm})$ で除した值とする.

\section{3. 解析結果の考察}

Fig. 2〜4に単純せん断試験の，ま た，Fig.5に一面せん断試験の DEM 解析の結果の一例を示している. 図中 の線分は接触点における法線方向およ び接線方向の弾性ばねによる接触力の 合力をベクトル表示したものであり， 接点を挟んで作用力と反作用力のベク トルを表わし，両者は大きさ等しく方

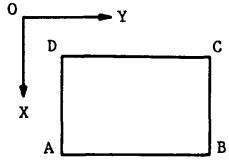

(a)

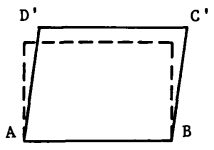

(b) simple shear

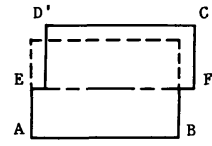

(c) direct shear
Fig. 1 Models of shear test for DEM analysis.

向が逆で一本の線分となる．この全線分長が図中の要素 直径長さに等しいとき接触力の大きさは約 75 個の要素 重量に相当する。

（1）静止状態ならびに圧縮特性

Fig.2〜5において，(a) 図は静止状態を表わすもの である.この解析は, 要素間ならびに要素-側壁間にご くわずかな間隙を残した非接触の浮遊状態から計算を開 始し, $\Delta t=10^{-4}(\mathrm{~s})$ 間隔で図中に示すそれぞれの時刻 $t_{0}$ まで繰り返すことによって静止状態 ${ }^{21}$ に至らしめたも のである. 静止状態に引続き, 圧縮 (圧密) 過程, せん 断過程と解析を進める。

圧縮は，供試体の上面に一定の圧縮荷重に相当する自 重をもたせた剛板要素（載荷板 CD）を付加することに よって行う. 同（b) 図はそれぞれの配列における圧縮 終了時の状態を表わしている．解析では剛板要素を上部 の粒子に接した状態から計算を開始し，図中に示すそれ ぞれの時刻 $t_{c}$ まで繰返し計算することによって剛板要 素を静止状態に至らしめた。この図では，供試体重量の 約 9 倍に相当する単位奥行き当たり $16 \mathrm{kgf}\left(\sigma_{x}=0.4\right.$ $\left.\mathrm{kgf} / \mathrm{cm}^{2}\right)$ の自重を㴊板要素に与えている.これらの図 に示す配列のうち, $11 / 12$ 配列は最も偏平な配列であり, 配列個数 $n$ を増やした $17 / 18$ 配列は高積み配列となる。 なお，接触力の縮尺は圧縮状態 $\left(\sigma_{x}=0.4 \mathrm{kgf} / \mathrm{cm}^{2}\right)$ を 基準として表わしているため, 静止状態（同図-a）にお ける接触力が小さくてほとんど図には表われていない. 静止状態（図 (a)) における粒子間の力の伝達性状は圧 縮終了時（図 (b)) とほとんど同じで，11/12 配列では 水平方向に近く, 配列個数 $n$ が多くなると鉛直成分を 増すそそれとともに，せん断容器側壁に作用する垂直力 は 11/12 配列で大きく $n$ の増加とともに減少する傾向 が認められる．ただ，作用力の大きさそのものは圧縮圧 力により著しく増大することは図にみられるとおりであ

Table 1 Dimensions of a particle and material constants used in DEM analysis.

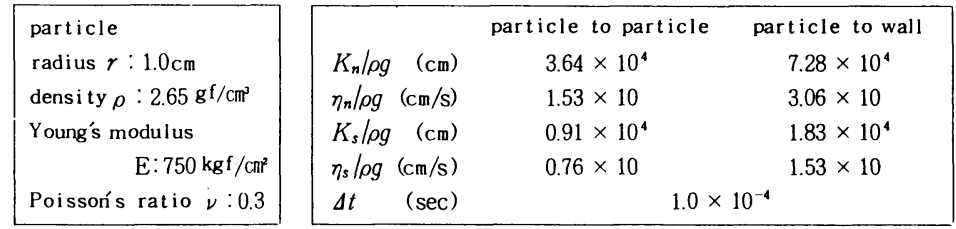



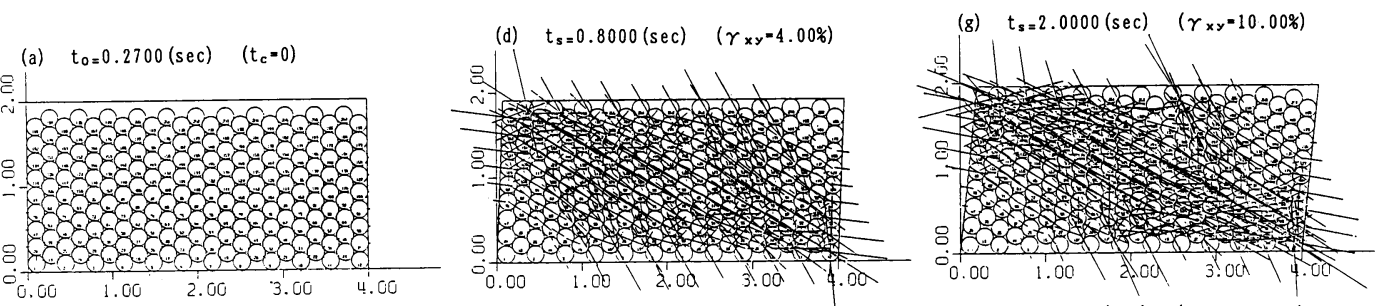

(b) $t_{c}=0.1176(\mathrm{sec}) \quad\left(t_{s}=0\right)$
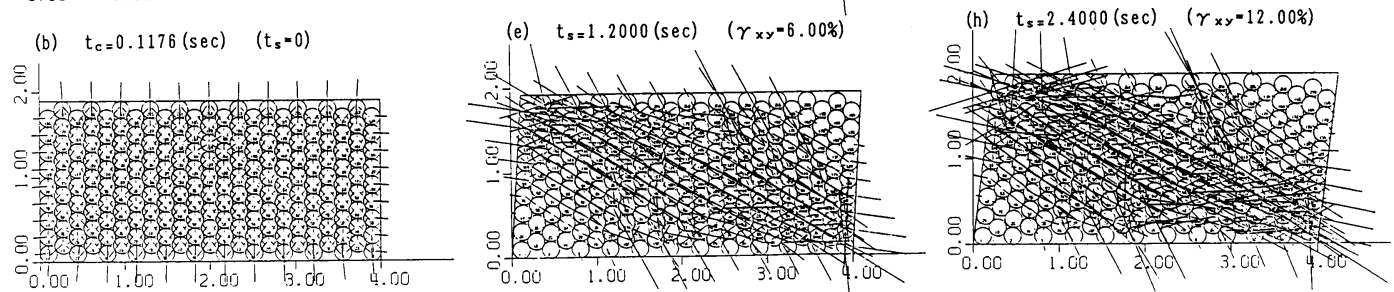

(c) $t_{s}=0.4000(\mathrm{sec}) \quad\left(\gamma_{x y}=2.00 \%\right)$
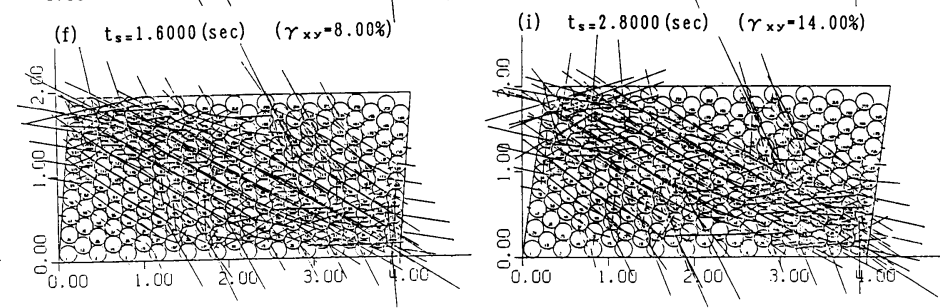

Fig. 2 Results of DEM analysis for simple shear test

$\left(11 / 12\right.$ arrangement, $\left.\sigma_{x}=0.4 \mathrm{kgf} / \mathrm{cm}^{2}\right)$.

(a) $t_{0}=0.1247(\mathrm{sec}) \quad\left(t_{c}=0\right)$

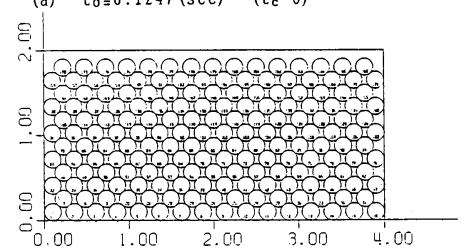

(b) $t_{c}=0.0966(\mathrm{sec}) \quad\left(t_{s}=0\right)$

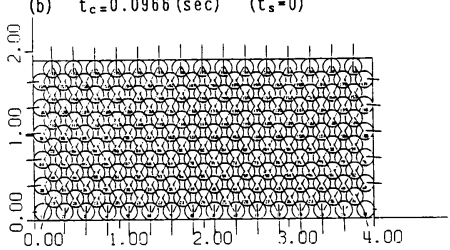

(c) $t_{s}=0.4000(\mathrm{sec}) \quad\left(\gamma_{x y}=2.00 \%\right)$

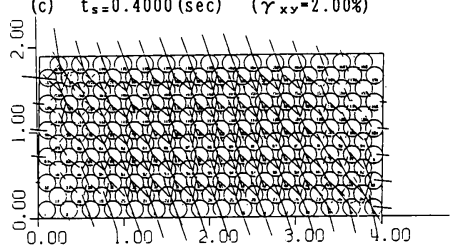

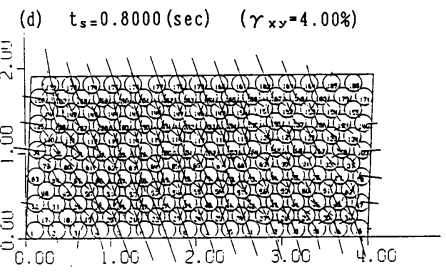

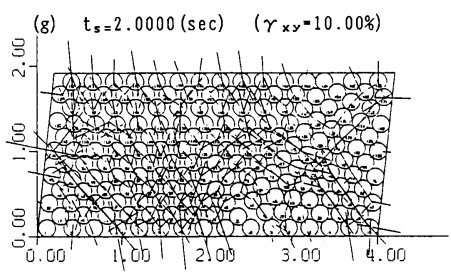

(e) $t_{s}=1.2000(\mathrm{sec}) \quad\left(\gamma_{x y}=6.00 \%\right)$
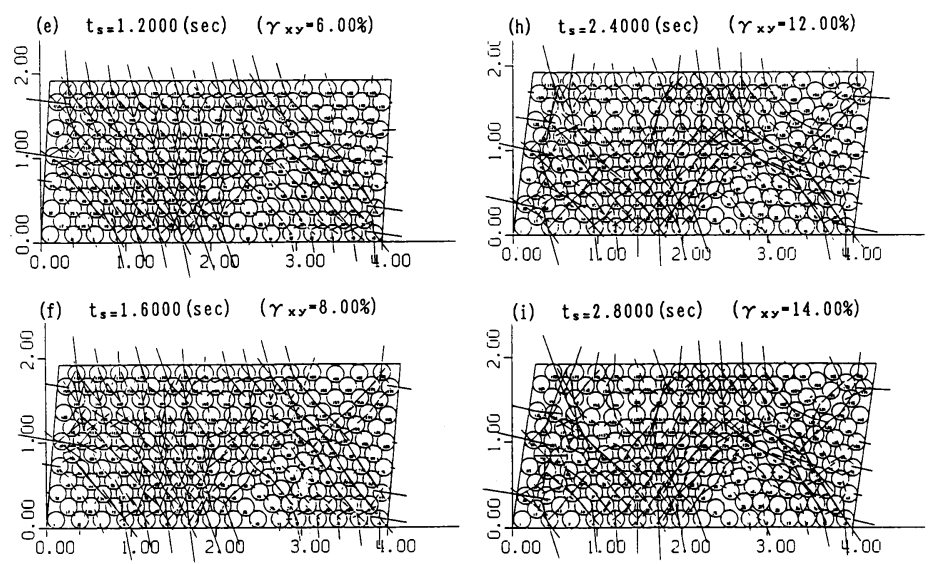

Fig. 3 Results of DEM analysis for simple shear test

$\left(15 / 16\right.$ arrangement, $\left.\sigma_{x}=0.4 \mathrm{kgf} / \mathrm{cm}^{2}\right)$. 
(a) $t_{0}=0.1156(\mathrm{sec}) \quad\left(t_{c}=0\right)$

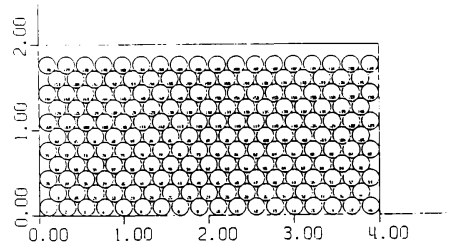

(b) $t_{c}=0.1050(\mathrm{sec}) \quad\left(t_{s}=0\right)$

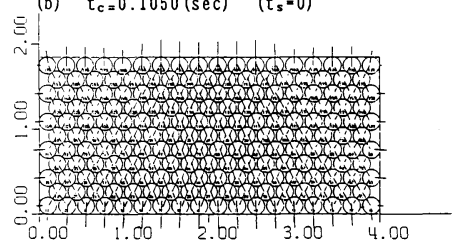

(c) $t_{s}=0.4000(\mathrm{sec}) \quad\left(\gamma_{x y}=2.00 \%\right)$

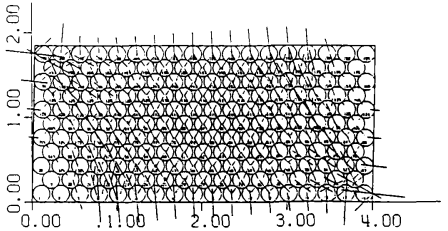

(d) $t_{s}=0.8000(\mathrm{sec}) \quad\left(\gamma_{x y}=4.00 \%\right)$

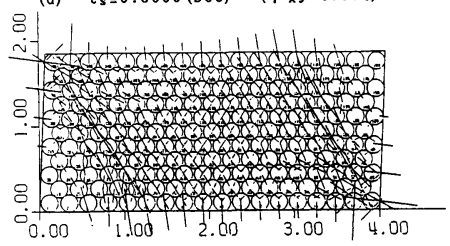

(e) $t_{s}=1.2000(\mathrm{sec}) \quad\left(r_{x y}=6.00 \%\right)$

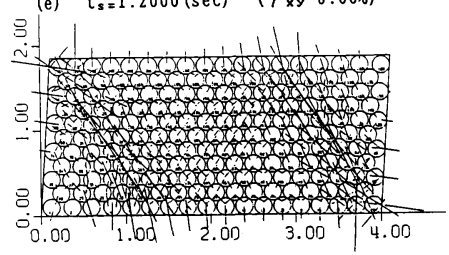

(f) $t_{s}=1.6000(\mathrm{sec}) \quad\left(\gamma_{x y}=8.00 \%\right)$

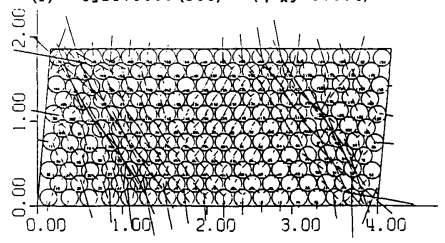

(g) $t_{s}=2.0000(\mathrm{sec}) \quad\left(\gamma_{x y}=10.00 \%\right)$

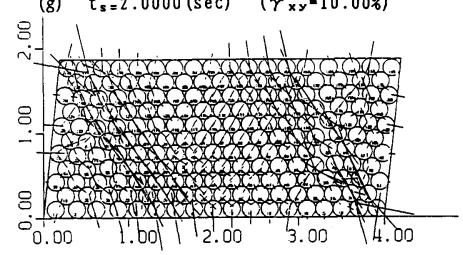

(h) $t_{s}=2.4000(\mathrm{sec}) \quad\left(\gamma_{x y}=12.00 \%\right)$
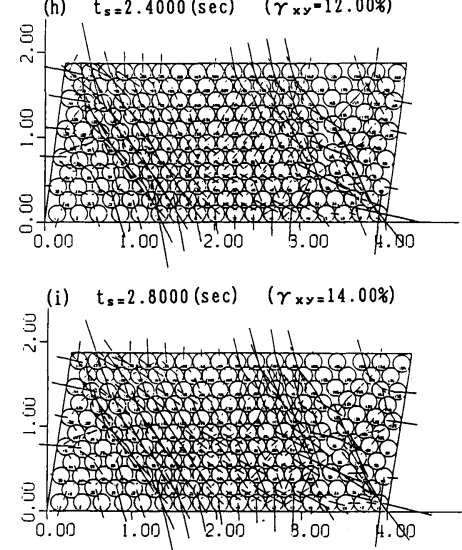

Fig. 4 Results of DEM analysis for simple shear test

$\left(17 / 18\right.$ arrangement, $\left.\sigma_{x}=0.4 \mathrm{kgf} / \mathrm{cm}^{2}\right)$.

$15 / 16$

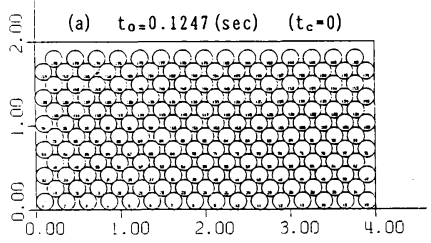

(b) $t_{c}=0.0966(\mathrm{sec}) \quad\left(t_{s}=0\right)$

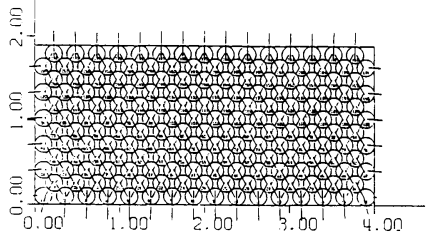

(c) $\mathrm{t}_{\mathrm{s}}=0.4000(\mathrm{sec}) \quad(\delta=0.40 \mathrm{~cm})$

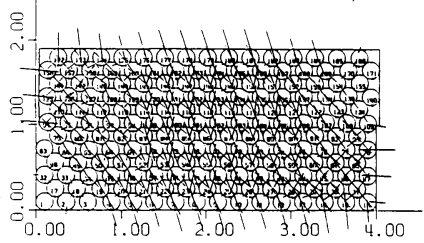

(d) $t_{s=0.8000}(\mathrm{sec}) \quad(\delta=0.80 \mathrm{~cm})$

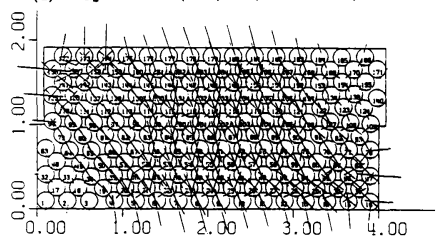

(e) $t_{s}=1.2000(\mathrm{sec}) \quad(\delta-1.20 \mathrm{~cm})$

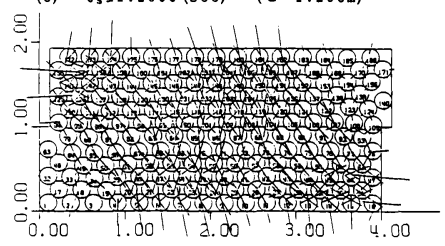

(f) $t_{s}=1.6000(\mathrm{sec}) \quad(\delta=1.60 \mathrm{~cm})$

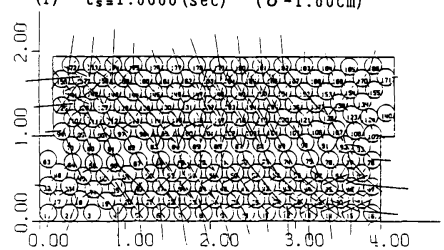

(g) $\mathrm{t}_{\mathrm{s}}=2.0000(\mathrm{sec}) \quad(\delta=2.00 \mathrm{~cm})$

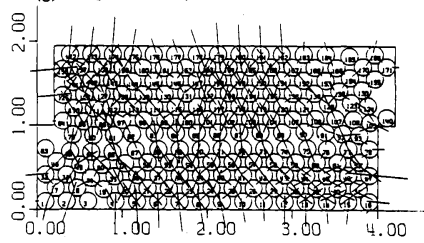

(h) $\mathrm{t}_{\mathrm{s}}=1.2000(\mathrm{sec})(\delta=1.20 \mathrm{~cm})\left[\begin{array}{ll}1 & 1\end{array} / 12\right]$

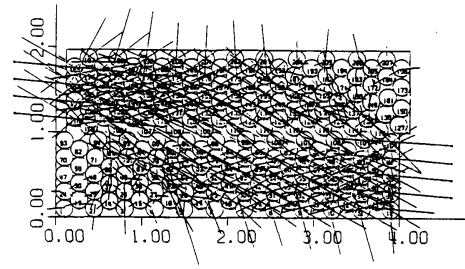

(i) $\mathrm{t}_{\mathrm{s}}=1.2000(\mathrm{sec})(\delta=1.20 \mathrm{~cm})[17 / 18]$

E.

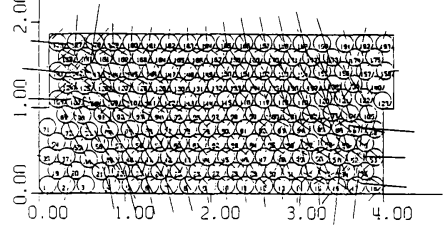

Fig. 5 Results of DEM analysis for direct shear test

$\left(15 / 16\right.$ arrangement, $\left.\sigma_{x}=0.4 \mathrm{kgf} / \mathrm{cm}^{2}\right)$. 
る.

\section{（2） せん断時の接触力分布と要素の挙動}

粒子間接触力は圧縮終了時には均一な分布を示してい る. せん断が開始されると（(c) 図以降)，せん断方向 に対し，正のダイレイタンシー角を示す接点では接触力 が大きくなり，逆に，負の接点では小さくなる傾向を示 し，変形に対する抵抗力が増加している。このような状 態において，最大せん断抵抗力が発揮される．さらに変 形が進むと，負の接点が消滅し，すぐ隣の要素を乗り越 す要素もみられるようになる。このような要素がある一 定の方向に集中的に生じて破壊面が形成される.

一面せん断試験の場合（Fig.5），これが中央部の仮想 せん断面に沿って観察され，強制的に破壊面が作られて いるのがわかる．この面以外では，このような挙動はま れであり，この部分以外では初期の規則的な配列が保存 されている.

一方，単純せん断試験の場合（Fig. 2, 3, 4)，一定の 面に集中する傾向はみられない。むしろ，供試体全体に わたって生じているようである。たとえば，最も明瞭な 破壊面を示した 15/16 配列（Fig.3）において，それは 上から 3 層目と 4 層目に観察されるが,この面以外でも， 乗り越し挙動を生じている．また，変形が大きくなると 乗り越すばかりでなく，すぐ下の空隙に落ち込む要素も 生じてくる.このように，単純せん断試験の場合，せん 断変形が進行したときの供試体全般にわたる配列の乱れ は大きなものとなっている.

壁面の接触力分布の変化についてみると, 両試験とも せん断が開始されると，強制的に変位させられる左上端 と右下端では大きくなり，逆に側壁との間に遊びの生じ
る右上端とその対角位置の左下端では, 小さくなってい る. また, 側面の接触力についてみると, 単純せん断試 験では側面 $\mathrm{AD}$ 上の接触力の鉛直成分は，常に上から 下へ，つまり膨張を妨げる方向に作用している．一方， 一面せん断試験の場合，変形初期は上から下へ作用する のに対し, 変形が進行すると ((f) 図以降), 下から上 へ膨張を助長する方向に作用している。この傾向は 13/14，15/16 配列において圧縮圧力が大きいほど顕著 となる。こうした壁面摩擦の存在については今後の研究 に待ちたい。

\section{（3）粒子配列とせん断特性}

ここでは,解析の結果をもとに,応力〜変位曲線やモ一 ル・クーロン破壊曲線を求め, 粒子配列がせん断特性に どのような影響を与えるかを考察する。

まず，単純せん断試験の結果について，11/12 配列， $15 / 16$ 配列，および $17 / 18$ 配列におけるせん断応力（ $\tau_{x y}$ $\left./ \sigma_{x}\right)$ とせん断ひずみ $\gamma_{x y}$, 直ひずみ $\varepsilon_{x}$ と $\gamma_{x y}$ の関係を Fig. 6 (a) （c) に示している. 17/18 配列では，ゆる やかに立ち上がり，明確なピークを示さない曲線になっ ているのに対し，15/16，11/12 と配列が偏平になるに つれ，立ち上がりも急で大きなピーク強度を示すように なる．これに対応して，体積膨張量も配列が偏平になる ほど大きなものとなっている，ゆる詰め，密詰めといっ た試料状態の違いによるせん断特性の相違か配列の変化 によって表現されている， $\tau_{x y} / \sigma_{x}$ のピークを破壊と考 え (Fig. 2 (g), Fig. 3 (c), Fig. 4 (d) がピーク時に 対応する状態である)，そのときの $\tau_{x y}$ と $\sigma_{x}$ の関係を Fig.7に示す.これより $c, \phi$ を求めると Table 2のよ うになる。ここに用いた $\sigma_{x}$ の大きさは $0.1 ， 0.2 ， 0.4$ $\left(\mathrm{kgf} / \mathrm{cm}^{2}\right)$ と低応力レベルである. $\phi$ は配列に依存し て変化しているのに対し，cには大きな変化はなく, 11/12 配列を除きごく小さな値しか生じない。そこで,

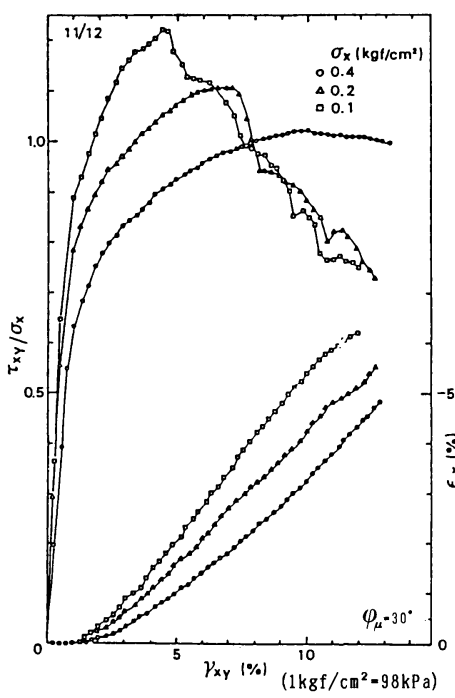

(a) 11/12 arrangement

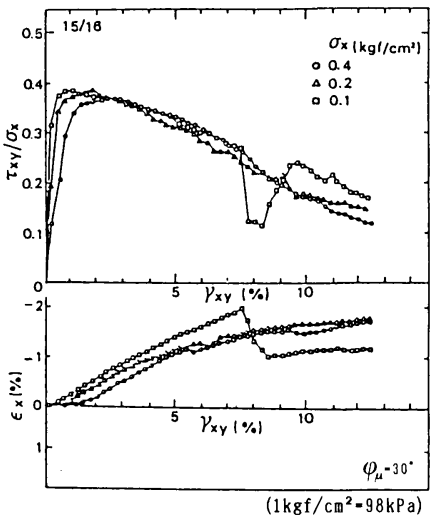

(b) $15 / 16$ arrangement

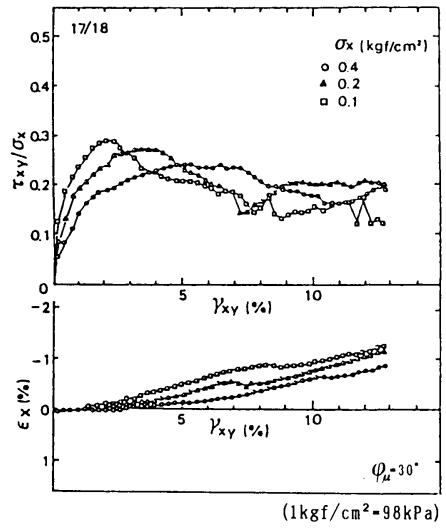

(c) $17 / 18$ arrangement

Fig. 6 Relationships among $\tau_{x y} / \sigma_{x}, \gamma_{x y}$ and $\varepsilon_{x}$ (simple shear test). 
$\phi$ について配列特性を表わす因子として粒子間接触角 $a$ (Fig.8（a)）を用いて整理してみるとFig.8（b）のよ うになり，粒子間接触角亡内部摩擦角の関係が，直線関 係で整理できることがわかる.

次に，一面せん断試験の結果についてみる.ここでは， 一例として Fig. 5 の 15/16 配列の場合について，前述の 結果と比較する。なお，同図 (h) には $11 / 12$ 配列，図

(i) には $17 / 18$ 配列の $\delta=1.2(\mathrm{~cm})$ の状態もあわせ て示している.Fig. 9 にこの解析から求められたせん断 応力〜ひずみ〜体積ひずみの関係を示している，せん断 応力〜ひずみ関係についてみると, 立ち上がり部分, ピー ク時, ピーク以後とも単純せん断試験（Fig.6 (b)) の 結果によく一致している．各配列につき， $c, \phi$ を求め てみると，Table 3 のようになる， $\phi$ は，単純せん断試 験に比べ $1 \sim 2^{\circ}$ 程度小さい值となる．また， $c$ について

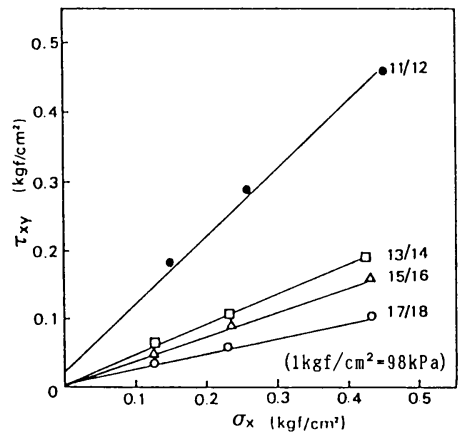

Fig. 7 Relationships between $\tau_{x y}$ and $\sigma_{x}$ at peak strength obtained from simple shear test $\left(\phi_{\mu}=30^{\circ}\right)$.

Table $2 c$ and $\phi$ obtained from simple shear test.

\begin{tabular}{|c|c|c|}
\hline & $\begin{array}{c}\mathrm{c} \\
\left(\mathrm{kgf} / \mathrm{cm}^{2}\right)\end{array}$ & $\begin{array}{c}\phi \\
(\mathrm{deg})\end{array}$ \\
\hline $17 / 18$ & $4.19 \times 10^{-3}$ & 12.7 \\
\hline $15 / 16$ & $5.59 \times 10^{-3}$ & 19.5 \\
\hline $13 / 14$ & $5.39 \times 10^{-3}$ & 23.4 \\
\hline $11 / 12$ & $4.67 \times 10^{-2}$ & 42.6 \\
\hline
\end{tabular}

$\left(1 \mathrm{kgf} / \mathrm{cm}^{2}=98 \mathrm{KPa}\right)$

Table $3 c$ and $\phi$ obtained from direct shear test.

\begin{tabular}{|c|c|c|}
\hline & $\begin{array}{c}\mathrm{c} \\
\left(\mathrm{kgf} / \mathrm{cm}^{2}\right)\end{array}$ & $\begin{array}{c}\phi \\
(\mathrm{deg})\end{array}$ \\
\hline $17 / 18$ & $3.97 \times 10^{-3}$ & 10.7 \\
\hline $15 / 16$ & $2.57 \times 10^{-3}$ & 18.8 \\
\hline $13 / 14$ & $1.33 \times 10^{-2}$ & 22.4 \\
\hline $11 / 12$ & $\left(-1.18 \times 10^{-3}\right)$ & 41.4 \\
\hline
\end{tabular}

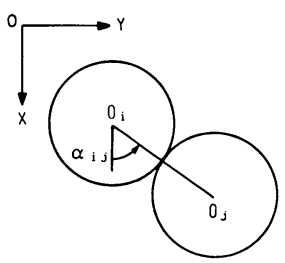

(a) interparticle contact angle $\alpha$

Fig. 8 Relationships between $\alpha$ and $\phi$ obtained from simple shear test $\left(\phi_{\mu}=30^{\circ}\right)$.
は，13/14 配列を除き，同様なごく小さな值であり配列 の影響も小さい.ところが，同一配列，同一鉛直応力下 で, 最大せん断強度が発揮されたのちの体積膨張量を比 較してみると,一面せん断試験の方が大きくなっている. 一面せん断試験の 15/16 配列以外の図は省略している が，配列が偏平になるほどその差は大きくなる．本解析 では，一面せん断試験の場合， $\delta=2.0(\mathrm{~cm})$ まで，また， 単純せん断試験の場合 $\gamma_{x y}=14.0(\%)$ まで変形させて いるが，最大で 11/12 配列の場合に 2〜3（\%）の差を 生じている．前節で，両試験のせん断中の破壊面形成の 違いおよびそれに伴う配列の乱れの違いについて述べ た. 一面せん断試験の場合, 破壊面以外での配列の乱れ は小さく，破壊面での乗り越し挙動により体積膨張が続 いている. 一方, 単純せん断試験の場合, 乗り越すばか りでなく, せん断の進行とともに供試体全体の乱れのた め, すぐ下の空隙に落ち込む挙動もみられ, 体積変化曲 線の勾配がゆるくなり，体積が減少する場合もある，両 試験にこのような顕著な差を生じたのは, 解析モデルに おいてせん断容器寸法と粒径の比が小さく, 1 つの粒子 の挙動が供試体全体の挙動に与える影響が大きかったこ とも一因と思われる.

\section{（4） 粒子間摩擦角 $\phi_{\mu}$ ，ばね定数比 $s$ の検討}

ここでは，残された材料特性として粒子間摩擦角 $\phi_{\mu}$ とばね定数比 $s$ （接線方向のばね定数 $K_{s}$ と法線方向の

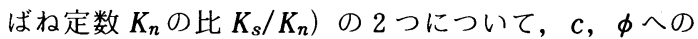
影響を考察する．たとえば，粒子間摩擦角 $\phi_{\mu}$ の大小が

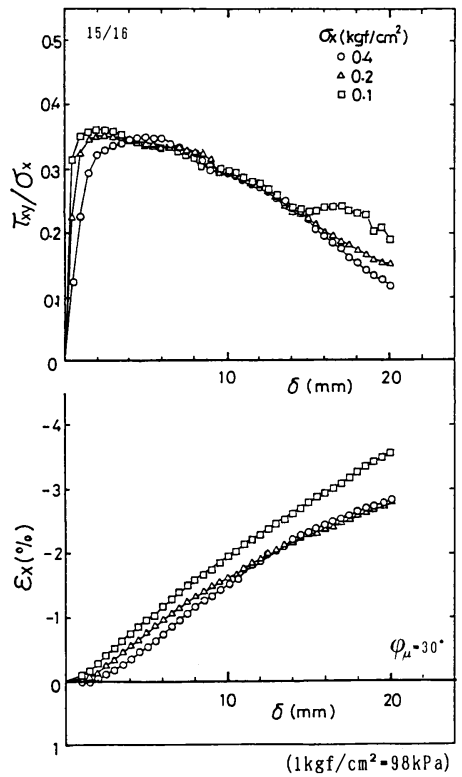

Fig. 9 Relationships among $\tau_{x y} / \sigma_{x}, \gamma_{x y}$ and $\varepsilon_{x}$ (direct shear test, $15 / 16$ arrangement) 


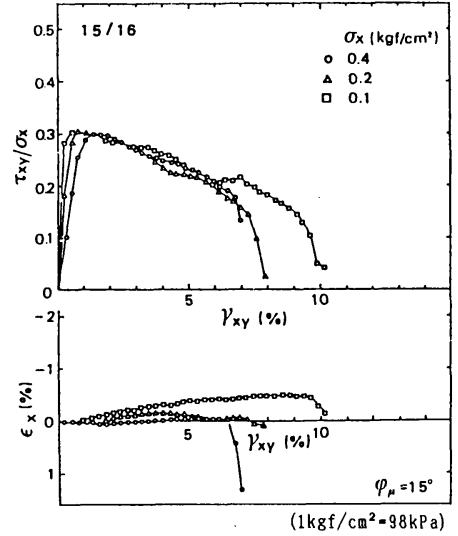

Fig. 10 Relationships among $\tau_{x y} / \sigma_{x}, \gamma_{x y}$ and $\varepsilon_{x}$ (simple shear test, $15 / 16$ arrangement, $\left.\phi_{\mu}=15^{\circ}\right)$.

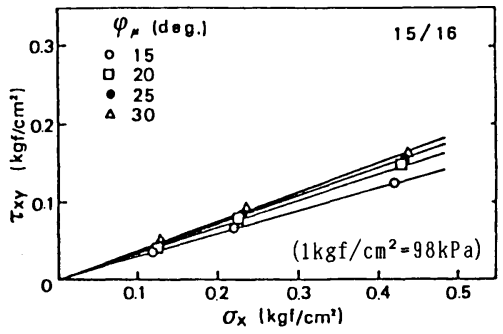

Fig. 11 Relationships between $\tau_{x y} / \sigma_{x}$ at peak strength obtained from simple shear test $\left(\phi_{\mu}=15^{\circ} \sim 30^{\circ}, 15 / 16\right.$ arrangement).

せん断特性に影響を与えることは想像に難くないが6) 他の材料特性や粒子配列の影響との量的関係は明らかで ない。なお，この節で述べる結果は単純せん断試験に対 してのみ行ったものである.

解析に用いた $\phi_{\mu}$ は前述の $30^{\circ}$ に加えて, $15^{\circ}, 20^{\circ}$, $25^{\circ}$ とした．配列は $15 / 16$ に固定しており，その他の条 件はすべて同一である. $\phi_{\mu}$ をさく採ったときのせん 断応力〜ひずみ関係および体積ひずみの特性を $\phi_{\mu}=15^{\circ}$ の例について Fig. 10 に示す. $\phi_{\mu}=30^{\circ}$ の Fig. 6 (b) に 比べ，ピーク強度に大きな差はみられないが，体積膨張 量は小さくなっている. これらの結果をもとに， $\phi_{\mu}=$ $15^{\circ} \sim 30^{\circ}$ について $\tau_{x y} \sim \sigma_{x}$ 関係をまとめると Fig. 11 の ようになる. $c$ は $\phi_{\mu}$ にかかわらずほぼ 0 とみなされ, $\phi$ は $\phi_{\mu}$ の増加とともにいくぶん増大の傾向を示すが (Fig. 12 参照), 配列の変化による影響に比べてこの変 化は無視できる.

次に, ばね定数比 $s\left(=K_{s} / K_{n}\right)$ の影響については, Fig. 13 にを $1.0,0.5$ および 0.25 としたときの $s$ と $\phi$ の関係を示している $(s$ を変えても $c \fallingdotseq 0$ は変わらな い). この結果より, $s$ の変化が $\phi$ へ及ぼす影響は無視 できることがわかる.

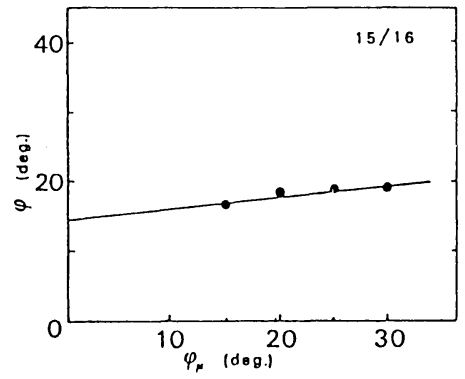

Fig. 12 Relationships between $\phi_{\mu}$ and $\phi$ obtained from the results of Fig. 11.

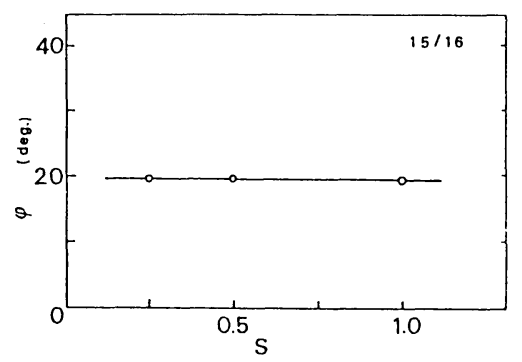

Fig. 13 Relationships between $s$ and $\phi$ obtained from simple shear test $\left(\phi_{\mu}=30^{\circ}\right)$.

\section{4. 結語}

Cundall の提案した離散剛要素法 (DEM) の実用解 析法としての確立のための基礎的検討を行っている.

本文では, 粒状集合体を取り扱う場合の要素の材料定 数の設定に際し, 集合体としての特性であるせん断強度 定数 $c, \phi$ が 1 つの指標となり得ると考え, せん断モデ ルの DEM 解析を実施した。等粒の円形要素を用いた 場合の特徴をまとめると次のようになる.

（1）内部摩擦角 $\phi$ は粒子配列に依存しており, 最 も偏平な $11 / 12$ 配列で大きく, 配列が高積みになるにつ れて小さくなる.この関係は, 粒子間接触角 $\alpha$ を用いて, $\phi \sim \alpha$ の直線関係で示し得る.

（2）粒子間摩擦角 $\phi_{\mu}$ やばね定数比 $s\left(=K_{s} / K_{n}\right)$ などの粒子個々の特性が, $\phi$ に与える影響は小さい.

（3）粘着力 $c$ は粒子配列, ばね定数比の変化に対 し，ほとんど変化せず，ごく小さな值しか生じない。

以上のことから, 粒状集合体の DEM 解析に際し, せん断強度特性 $c, \phi$ の 素でモデル化する場合, 要素個々の材料定数 $K, \eta, \phi_{\mu}$ 等の設定は比較的自由であり, 第一近似は粒子間接触角 $\alpha$ で代表される粒子配列によって対応すべきであると結 論される.ただし，等粒の円形要素を用いた今回の DEM 解析で, 粘着力 $c$ の再現は果たされていない. なお, 本解析は, 計算に京都大学計算機センター 
FACOM M-382, また, 入出力処理に鳥取大学計算機 センターHITAC M-150を使用した.

\section{参 考 文 献}

1) Cundall, P.A. : A Computer Model for Simulating Progressive, Large Scale Movements in Blocky Rock Systems, Symp. ISRM, Nancy, France, Proc. Vol. 2, pp. 129 136, 1971.

2）木山英郎・藤村 尚：カンドルの離散剛要素法を用いた 岩質粒状体の重力流動の解析, 土木学会論文報告集, 第 333 号, pp. 137 146, 1983.
3）藤村 尚ほか：岩石の DEM 定数決定のための落下反発 試験, 土木学会第 41 回年次学術講演会講演概要集, pp. 369 370, 1986.

4）木山英郎 - 藤村 尚 -二木 隆 : 粒状体地盤の離散剛要 素法解析と模型実験一地下浅所のトンネルによる地盤変 形一，材料，第 392 号, pp. 466 471，1986.

5) Rowe, P.W. : Stress-Dilatancy Relation for Static Equilibrium of An Assembly of Particles in contact, Proc. Royal Soc., London, Series A, Vol.269, pp. 500 $\sim 527,1962$.

（1986.10.1 • 受付） 